\title{
Killing, karma and caring: euthanasia in Buddhism and Christianity
}

\author{
Damien Keown and John Keown Goldsmiths, University of London and Cambridge University respectively
}

\section{Abstract}

In 1993 The Parliament of the World's Religions produced a declaration known as A Global Ethic which set out fundamental points of agreement on moral issues between the religions of the world. However, the declaration did not deal explicitly with medical ethics. This article examines Buddhist and Christian perspectives on euthanasia and finds that in spite of their cultural and theological differences both oppose it for broadly similar reasons. Both traditions reject consequentialist patterns of justification and espouse a 'sanctity of life' position which precludes the intentional destruction of human life by act or omission.

\section{Introduction}

The religions of the world are becoming increasingly aware that what unites them in ethics is greater than what divides them in theology. An interesting counterpoint to the disintegration of moral consensus in the postmodern world can be seen in the impetus towards dialogue and mutual understanding on the part of traditions which for much of their history have been antagonistic. As they search their ancient teachings for solutions to contemporary dilemmas, Christians, Muslims and Jews are becoming increasingly aware of the common ground they share. The consensus which is emerging in key areas suggests that scepticism regarding moral objectivity may be misplaced.

The moral consensus among religions was given expression in a codified form by the Parliament of the World's Religions which met in Chicago in late 1993. The parliament produced a declaration which reveals an impressive degree of accord. The declaration states: "We affirm that a common set of core values is found in the teachings of the religions, and that these form the basis of a global ethic' (1). In its affirmation that there is 'an irrevocable, unconditional norm for all areas of life, for families and communities, for races, nations and religions' (1)

\section{Key words}

Death and dying; religious ethics. it characterises these core values as objective and universal moral truths.

Adding further weight to the suggestion that a consensus on ethical fundamentals exists among the major religious traditions are the views of the eastern religions, whose voice has been little heard to date. Perhaps the most influential of these is Buddhism, a religion whose adherents in Asia number roughly 500 million and which is rapidly making inroads in the West. Arnold Toynbee has described the encounter between Buddhism and Christianity as 'one of the greatest collisions of the 21 st Century,' (2) and although it is too soon to predict the outcome of this encounter it is undeniable that it will be of significance. The purpose of this paper, however, is not to speculate about the future, and is limited to indicating the existence of common ground in one specific area of medical ethics, namely euthanasia. By 'euthanasia' we mean the intentional killing of a patient by act or omission as part of his or her medical care. We are not concerned, therefore, with either the administration of palliative drugs, or the withdrawal of futile or excessively burdensome treatment, which may, as a foreseen side-effect, hasten death.

\section{Buddhist ethics}

Reliable information on Buddhism has been available in the West for less than a century and a half and the study of Buddhist ethics is a nascent discipline. The existence of alien traditions such as Buddhism has long been seen as providing evidence of moral diversity and support for moral relativism. A closer examination, however, suggests that this view is mistaken. What is particularly striking in the case of Buddhism (3) is that despite its different theological premises (most radically its denial of both a supreme being and the soul), it reaches ethical conclusions which are very similar to those of the Semitic religions.

In terms of the categories of Western ethics Buddhism could best be summed up as a teleological virtue ethic. Its nearest analogue would be Aristotle's eudaimonism as developed in the tradition of natural 
law (4). In its teachings on karma Buddhism affirms that every moral act has both transitive and intransitive effects. The transitive effects are seen in the impact our moral choices have on others, while the intransitive effects are the changes in the character of the subject brought about through the performance of virtuous or wicked deeds. The doctrine of karma also holds that the circumstances of rebirth are determined by an individual's moral status at death. This means that the hedonic tone of any given existence is conditioned by antecedent moral deeds. While moral actions produce pleasant and unpleasant consequences in the form of transitive and intransitive effects, however, the moral status of an act is not determined by its consequences. For Buddhism this is determined instead by the conformity between what is intended and the eternal moral law (Dharma), the requirements of which can be known through scripture and reason (5).

\section{The sanctity of life}

Buddhism's approach to medical ethics is informed by its belief in the sanctity of life. This pan-Indian belief finds ethical expression among the major religious traditions in the form of the principle of nonharming (ahimsā). In the case of Buddhism, which is atheistic, respect for life is grounded not in its divine origin but in its spiritual destiny, namely the state of final perfection known as nirvana. From this affirmative valuation of life flow precepts forbidding its intentional destruction (6).

Despite its highly sophisticated psychology Buddhism makes no attempt to distinguish certain faculties as indicators of moral personhood. Existence is a continuum of changing states: all states are impermanent, and the possession or absence of certain faculties or qualities in the course of a determined psycho-physical existence is of no moral significance. Individual life in any one existence begins at conception and ends at death: in the interval between the subject is entitled to full moral respect regardless of the stage of psycho-physical development attained or the mental capacities enjoyed (7).

\section{Euthanasia}

No euphemism such as 'euthanasia' is found in early Buddhist canonical sources, nor is the morality of the practice discussed specifically in the discourses (sutta) of the Buddha (8). As an act or omission involving the intentional destruction of life, however, it would undoubtedly be prohibited by Buddhist precepts. Confirmation of this can be found in the Monastic Rule (Vinaya), a corpus of canonical literature which sets out the regulations governing monastic life. The Monastic Rule is an authoritative source for Buddhist ethics, and includes a body of case law in which the Buddha is represented as giving judgment on specific matters. The cases relevant to euthanasia are recounted under the rubric of the precept against the destruction of human life (the third pāräjika). The penalty fote breaking the precept is the severest which can be imposed: lifelong excommunication.

The circumstances leading to the promulgation of this precept have a direct bearing on euthanasia. Theo Buddha included it in the monastic code on dis $\overline{\bar{S}}$. covering that a number of monks had either killed themselves or asked others to kill them after devel-n oping disgust for their bodies, an attitude not unknown in ascetic traditions. Some monks com- $\overrightarrow{0}$ mitted suicide, some killed one another, and others invoked the aid of an assistant from outside the ordero who killed them with a knife. When the Buddhas found out he immediately took action to prevent any recurrence by introducing a precept forbidding the destruction of human life. The precept expressly forbids both killing a human being and seeking్ assistance in dying (literally 'looking for a knife-o음 wielder') (9).

The promulgation of the precept in these cir- $\vec{O}$ cumstances suggests that voluntary euthanasiaf (that is, euthanasia at the individual's request) iso immoral from a Buddhist perspective. The fact that the monks were autonomous agents seems to haveco had no bearing on the matter, which implies thater the principle of the sanctity of life cannot be ove ridden by an appeal to autonomy. It is arguales that the prohibition was introduced because the monks who sought euthanasia in the case in poin had done so under the influence of religious zea: and without due time for sober reflection. This argument is, however, unpersuasive, since the precept imposes an unqualified prohibition. Such aे prohibition is, moreover, quite consistent with the corpus of early Buddhist ethical teachings which do not contemplate any circumstances in which the destruction of life might be condoned (10). Inoaddition there are further cases in the Monastic Rule itself where the immorality of euthanasiob clearly does not turn on the absence of due consideration. Certain of these cases involveo 'quality of life' issues: one concerns terminal care (11), and two the long-term care of patients with? serious disabilities (amputated limbs) (12).

The most interesting of these cases is the first ${ }_{3}^{N}$ the one involving terminal care. The motive is stated to have been compassion for the suffering ofu a dying monk. According to the influential fifthcentury commentator Buddhaghosa, those foun $\oint_{b}$ guilty in this case took no direct action to terminate्ष life but merely suggested to a dying monk that? death would be preferable to his present condition.0 Despite this apparently benevolent motive, namelye् to spare a dying person unnecessary pain, the judgment handed down was that those involved $\vec{B}$ were guilty of a breach of the precept. What hado they done wrong? In Buddhaghosa's view the essence of their wrongdoing was that the guilty 
monks made death their aim (Va.ii.464). It would therefore appear immoral from a Buddhist perspective to embark on any course of action whose aim is the destruction of human life, regardless of the agent's motive (13).

The circumstances in which the precept was promulgated and the cases referred to above are directly relevant to the two main grounds on which euthanasia is thought by some to be justifiable, namely beneficence, either in alleviating pain or terminating life which is no longer thought to be a benefit, or respect for autonomy. The canonical evidence suggests that neither of these grounds provides justification for euthanasia from a Buddhist perspective.

The above does not, however, commit Buddhism to the view that life must be preserved at all costs. Buddhism is only too aware of the fragile and transitory nature of life, but as individual life is a continuum which constantly re-manifests itself Buddhism does not seek to prolong it by artificial means simply because it is technologically possible. There is accordingly no requirement to carry out futile or unduly burdensome treatments, such as resuscitating the dying. The intentional hastening of death is, however, morally unacceptable in all circumstances.

\section{Christian ethics}

Given the number of Christian denominations, and their more or less varying traditions, it is hardly surprising that not all Christians agree on all ethical issues. The major Christian tradition, Catholicism, subscribes to an ethics based on natural law, whereas the Lutheran churches do not. Nevertheless, both traditions would join in rejecting a consequentialist ethic, one which holds that the morality of an action turns solely on its consequences, an ethic advanced by a number of prominent contemporary bioethicists.

The Christian tradition rejects such bioethicists in favour of St Paul, who taught that certain conduct is intrinsically wrong and should be avoided regardless of any good consequences that might flow from it. In short, a good end does not justify a bad means: evil may not be done that good may come of it (14). Christian ethics holds that, while consequences may well be relevant in assessing the morality of an act or omission, the morality of an act or omission is not determined by its consequences. So whereas the Christian rules out, say, torturing children as intrinsically wrong, the consequentialist does not. This is not the place to critique consequentialism; its incoherency has been exposed elsewhere (15). Our purpose here is simply to note the consensus among Christians and Buddhists in rejecting the consequentialist ethical approach which typically underlies the case for the legalisation of euthanasia.

\section{The sanctity of life}

Few ethical concepts are more widely misunderstood or persistently misrepresented than that of the 'sanctity of life'. As developed and understood in Christian thought, it holds that as life is a gift from God it is to be cherished. As explained by the Anglican and Catholic bishops in their joint submission to the House of Lords Select Committee on Medical Ethics (a submission which states that it would also enjoy the support of the Free Churches): 'All human beings are to be valued, irrespective of age, sex, race, religion, social status or their potential for achievement' (16) and 'the deliberate taking of human life is prohibited except in self-defence or the legitimate defence of others' (17). In this understanding, which roots the fundamental value of each human being in his or her creation by God and in the image of God (but which can also be articulated in purely secular terms) human life is a basic good as opposed to an instrumental good: a good in itself rather than as a means to an end, whether that end be conceived of as life of a certain minimum 'quality', or the good of the state, or anything else.

Life is not, however, considered to be an absolute value, in the sense that it must be preserved at all costs. As the bishops make clear: 'Neither of our Churches insists that a dying or seriously ill person should be kept alive by all possible means for as long as possible' (18). They add that it can be perfectly proper to administer palliative care even if it incidentally shortens life. Adverting to the doctrine of 'double effect', they note that 'There is a proper and fundamental ethical distinction ... between that which is intended and that which is foreseen but unintended' (19).

\section{Euthanasia}

The principles sketched above explain the basis of the Christian opposition to euthanasia. As the wrongness of intentional killing obtains regardless of the consequences, that opposition applies whatever the condition of the patient. As the joint submission states, the vulnerable deserve not less protection, but 'special care and protection' (20). Adherence to this principle, it adds, 'provides a fundamental test as to what constitutes a civilised society' (20).

Even euthanasia at the patient's explicit request is to be prohibited. The right to personal autonomy is not absolute: 'It is valid only when it recognises other moral values, especially the respect due to human life as such, whether someone else's or one's own' (18). Moreover, the exercise of autonomy has to be limited in order that human beings may live together in reasonable harmony.

Allied to this principled objection to voluntary euthanasia are two other objections which focus on the undesirable consequences of tolerating it. First, that 'it would be difficult to be sure that requests for euthanasia were truly voluntary and settled, even if 
safeguards were built into the legislation, and not the result either of depression or of undue pressure from other people' (21). Second, that it would result in a breakdown of trust between doctor and patient (22).

It would be a grave error to perceive the Christian opposition to euthanasia as a rejection of the problems of the terminally ill. The submission notes that the hospice movement grew out of the concerns of Christians that people should be helped to die with dignity and it urges that the lessons learned in hospices should be applied throughout the health service to all dying people (23). It concludes that it is killing, rather than caring, which denies the dignity of the dying.

\section{Conclusion}

Five main conclusions may be drawn about euthanasia in Buddhism and Christianity. First, despite the widely different cultural background and theological presuppositions informing both religious traditions, there is a striking similarity in their opposition to the intentional killing of patients. Secondly, this opposition is not coincidental but derives from their shared rejection of consequentialist reasoning in favour of an ethical approach grounded in a respect for human life as a basic as opposed to an instrumental good. Thirdly, notwithstanding this shared absolute opposition to euthanasia, both religions teach that life is not an absolute value to be preserved at all costs and both emphasise the transistory nature of earthly existence. Fourthly, the remarkable consensus between these major but disparate religious traditions calls into question prevalent assumptions about the impossibility of moral consensus in the modern world. Finally, the common conclusions identified by this investigation of the issue of euthanasia lends support to the conviction articulated in the declaration of the Parliament of the World's Religions that a common set of core values may be found in the teachings of the world religions.

Damien Keown is Lecturer in Indian Religion at Goldsmiths, University of London and co-editor of the Journal of Buddhist Ethics. Fohn Keown is Lecturer in the Law and Ethics of Medicine at Cambridge University and a Fellow of Queens' College, Cambridge.

\section{References and notes}

(1) Küng $\mathrm{H}$ and Kuschel K J, eds. A global ethic. The declaration of the parliament of the world's religions. London: SCM Press, 1993: 14. Other recent discussions include Runzo J, ed. Ethics, religion and the good society: new directions in a pluralistic world, Louisville: John Knox Press, 1992; Outka G, Reeder J P, eds. Prospects for a common morality, Princeton: Princeton University Press, 1993. A selection from the speeches made at the first parliament in 1893 may be found in Seager $\mathrm{R} \mathrm{H}$, ed. The dawn of religious pluralism. Voices from the world's parliament of religions, 1893. La Salle, Illinois: Open Court, 1993. The declaration is not, of course, a comprehensive exposition of the views of the signatories. Some find the declaration incomplete in certain respects. See, for example, Waldau P. Beyond praise of the 'declaration of the parliament of the? world's religions'. Studies in interreligious dialogue $\overrightarrow{\bar{c}_{3}}$ 1995; 5: 76-89.

(2) Toynbee A. Christianity among the religions of the world London: OUP, 1948:14. See also Keown D. Christian ethics in the light of Buddhist ethics. Expository times 1995; 106, 5: 132-137.

(3) There are many schools of Buddhism and no centralo authority on matters of doctrine. There is, however, a consensus on ethics among the main schools. For the $\vec{\circ}$ purposes of this article the Theravāda School, which $\bar{\square}$ is the oldest and most orthodox of the surviving tradi-w tions, is taken as representative of the Buddhist position.

(4) See Keown D, The nature of Buddhist ethics. London:고 Macmillan, 1992.

(5) The Buddhist term is prajñā which might be trans $v$ lated as 'rational insight'. Like the Greek sophia, S prajñ $\bar{a}$ denotes the cognitive faculty whose function iso the intuitive apprehension of truth. Prajĩna is not a self-validating mystical intuition and is always $\vec{O}$ grounded in, and justifiable through, reason.

(6) A fuller discussion of these matters may be found in Keown D. Buddhism and bioethics. London:్ㅡㄴ Macmillan, 1995: ch 1.

(7) For a fuller discussion see reference (6): Buddhism and bioethics: 21-36.

(8) Secondary literature on the subject is also scant. The most useful article to date is Florida R E. Buddhōit approaches to euthanasia. Studies in religion/scien religieuses $1993 ; 22$ : 35-47, which contains referenceso to most of the available sources.

(9) The precept states: 'If any monk should intentionally deprive a human being of life or look for a knife- $\overrightarrow{\overrightarrow{0}}$ wielder he commits the offence of defeat (päräjika) 3 and is no longer in communion' (Vinaya iii.71). The? instrument used is of no significance: the embeddedo commentary explains that the lethal instrument may be a knife, a dagger, an arrow, a cudgel, a stone, a sword, poison or a rope (Vinaya iii.73).

(10) Even killing in self-defence appears to be ruled out (Anguttara.iv.188).

(11) Vinaya.ii.79.

(12) Vinaya.ii.86.

(13) In Buddhism, as in other religions, there exists the category of mors voluntaria religiosa. This relates to cases where pious individuals or saints, often under the influence of religious zeal, sacrifice their lives forv some religious end. Three notable cases are found in ${ }^{\mathrm{r}}$ the Pali canon, and many more (often fictitious) are $\mathrm{O}$ scattered throughout later literature. Although these examples are sometimes thought to show that Buddhism condones suicide (and would therefore invalidate the principle stated above) we think it would be unwise to draw normative conclusions from these examples, especially since suicide is elsewhere clearly prohibited (for example by the First Precept and also by the Monastic Rule, as seen above). A brief discus- $\frac{\text { त }}{\mathbb{D}}$ sion of the anomalous category of voluntary religious death and its implications for ethics will be found in $\vec{\Phi}$ Buddhism and bioethics: 58-60. For a discussion of voluntary death in the context of another Indian tradition, Jainism, see Bilimoria P. The Jaina ethic of voluntary death. Bioethics 1992; 6: 330-355. With 
reference to Judaism and Christianity see Droge A J, Tabor J D. A noble death: suicide and martyrdom among Christians and fews in antiquity. San Francisco: Harper Collins, 1991. With reference to classical antiquity see van Hooff A J L. From autothanasia to suicide. Self-killing in classical antiquity. London: Routledge, 1990.

(14) The Holy Bible. Letter of Paul to the Romans, 3:8.

(15) See, for example, Grisez G. Against consequentialism. American journal of jurisprudence 1978; 23: 21-73; Finnis J M. Fundamentals of ethics. Oxford: OUP, 1983: ch IV.
(16) Joint Submission of the Anglican and Catholic Bishops to the House of Lords Select Committee on Medical Ethics. Euthanasia - no! London: The Incorporated Catholic Truth Society, 1993: para 3.

(17) See reference (16): para 13.

(18) See reference (16): para 8.

(19) See reference (16): para 14.

(20) See reference (16): para 4.

(21) See reference (16): para 12.

(22) See reference (16): para 17.

(23) See reference (16): paras 20-21.

\section{News and notes}

\section{Psychiatry, Law and Ethics}

The next formal meeting of the Section of Psychiatry, Law and Ethics of the World Psychiatric Association section will be held in Sun City, South Africa during the 11 th World Congress of Medical Law, July 28 to August 1, 1996. Psychiatry Law and Ethics will be the major topic at the congress. Members of our section are hereby asked to send the titles of their proposed papers to the organizing committee: PO Box 51, Buhrmannsdrif, 2867, Northwest, South Africa with copies to Professor A Carmi, PO Box 6451, Haifa 31063, Israel. The 10th World Congress of Psychiatry will be held in Madrid, August 23rd to August 28th, 1996 and members are expected to attend this important event as well.

\section{News and notes}

\section{Terminally ill and dying patients}

The CEREC Center of Southeast Florida, an independent program for the advancement of Clinical Ethics Research, Education and Consultation, is holding a clinical ethics seminar on Ethical Issues in the Care of Terminally Ill and Dying Patients, December 15-18, 1995, at the Rolling Hills Hotel and Golf Resort, Ft Lauderdale, Florida. CEREC Seminars combine lectures by renowned bioethicists with participant presentations and parallel sessions on clinical cases. Only 45 participants will be admitted to foster an atmosphere of interdisciplinary dialogue and critical discussion. For more information, contact: Dr Jos V M Welie, CEREC Center, PO Box 292932, Ft Lauderdale, FL 33329. Tel/Fax: (305) 424-9304. Email: jwelie@bcfreenet.seflin.lib.fl.us.

CEREC's next two seminars will be: Ethical Issues in Renal Dialysis and Kidney Transplantation, April 26-28, 1996, and Ethical Issues in the Care of Incompetent Patients, August 23-25, 1996. 